\title{
2軸1舵船の操縱運動簡易推定法
}

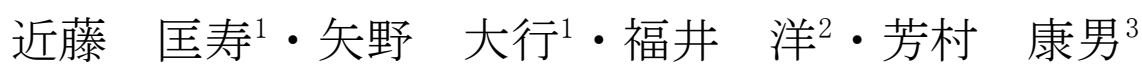

\section{Simple Simulation Model for Manoeuvring Ship Motion of Twin-propeller and Single-rudder Ships}

\section{Masatoshi KONDO, Hiroyuki YANO, Yo FUKUI and Yasuo YOSHIMURA}

\begin{abstract}
Twin-propeller and Single-rudder Ships are frequently used for medium high-speed ships such as container ships and passenger ferry. However, the manoeuvring simulation for these ships is not easy because the interaction forces between propellers and rudder become very much complicated.

In this paper, the authors have investigated a simple analysis and simulation technique for manoeuvring ship motion of twin propeller and rudder ships. For this purpose, captive model tests have been carried out, where the propeller thrusts and rudder normal force as well as ship hull forces are obtained for various parameters including propeller rps and rudder angle. Although the propeller thrusts are slightly different in each other for port and starboard sides and this makes the additional yaw moment, the thrust is assumed to be a single propeller's one by means of combining the both sided thrusts as if the ship is a single propeller and rudder ship. In this analysis, the propeller diameter is assumed to be $\sqrt{2}$ times larger and propeller rps $1 / \sqrt{2}$ times, so that the thrust coefficient $K_{T}$ becomes the average thrust coefficient of twin propellers. This assumption can make very simple and easier since the conventional mathematical model for single propeller and rudder ships can be applied.

In order to validate the above method, free-running model tests have been carried out and compared with the simulated results. As the result, it is found that this simple technique becomes very useful for the simulation of twin-propeller and single-rudder ships.
\end{abstract}

Keywords : Manoeuvrability, Twin-propeller single-rudder ships, Interaction coefficients, Mathematical model キーワード: 操絟性能, 2 軸 1 舵船, 干渉係数, 数学モデル

\section{1. 緒 言}

高速化が要求される船舶では 2 軸船型が採用され ることが多い。2 軸 2 舵船は、低速時の舵効きが良 好で、特に港内の操縦性能に優れているが、建造コ ストや推進性能の面において 2 軸 1 舵船の方が優れ ている。最近では、省エネルギーの観点から、2 軸 1 舵が採用されることも多い。

2 軸 2 舵船の操縦性の研究は、芳村 ${ }^{(4)}$ 、李 ${ }^{(5)}$ など
による詳細な研究があるが、2 軸 1 舵船については 意外と少ない。古くは玉井ら ${ }^{(1)}$ の研究があるが、実 船試験結果や自由航走模型試験結果にとどまってい る。これに対して湯室 ${ }^{(2)}$ は、流体力学的な見地から 研究を行っているが、残念ながら船体は存在せず、 プロペラ・舵にとどまっている。2 軸 1 舵船の操縦 運動を、流体力学的背景に基づいて予測するには、 船体・プロペラ・舵の干渉係数の取り扱いを明確に

\footnotetext{
学生会員 北海道大学大学院水産科学院（干041-8611 函館市港町 3-1-1） mskondo@eis. hokudai. ac. jp 正会員ジャパンマリンユナイテッド(株)

正会員 北海道大学水産科学研究院（干041-8611 函館市港町 3-1-1） y-yoshi@fish. hokudai.ac. jp
} 
することが不可欠となる。しかし、左右のプロペラ が船体中心線上の舵に及ぼす影響は、舵がプロペラ 直後に無いことから 2 軸 2 舵船より複雑である。

本論ではこうした点を踏まえ、拘束模型試験を実 施して、操縦運動推定法の検討を行った。その際、 数学モデルは、実績のある 1 軸 1 舵船用の $\mathrm{MMG}$ 数 学モデル(3)を基本にし、それに 2 軸 1 舵の特徽を加 えることとした。供試船は 2 軸 1 舵のフェリーとし、 その主要目を表 1 に、模型船の写真を図 1 に示寸。

表 1 供試船の主要目

\begin{tabular}{|ll|l|}
\hline \hline$L_{P P}$ (垂線間長) & $(\mathrm{m})$ & 2.344 \\
\hline$B \quad$ (型幅) & $(\mathrm{m})$ & 0.356 \\
\hline$d_{m}$ (平均喫水) & $(\mathrm{m})$ & 0.100 \\
\hline トリム & $(\mathrm{m})$ & 0. \\
\hline$\nabla$ (排水容積) & $\left(\mathrm{m}^{3}\right)$ & 0.0443 \\
\hline$x_{G}$ (重心前後位置) & $(\mathrm{m})$ & -0.100 \\
\hline$D_{P}$ (プロペラ直径) & $(\mathrm{m})$ & $0.0756 \times 2$ \\
\hline$P / D_{P}$ (ピツチ比) & & 1.103 \\
\hline 回転方向 & & 外回り \\
\hline 軸間距離 $/ D_{P}$ & & 1.32 \\
\hline$\Lambda$ (舵アスペクト比) & & 1.470 \\
\hline$\eta\left(=D_{P} /\right.$ 舵高さ) & & 0.879 \\
\hline$A_{R} /\left(L_{P P} d_{m}\right)$ & & $1 / 46.7$ \\
\hline \multicolumn{2}{|l}{} \\
\hline
\end{tabular}

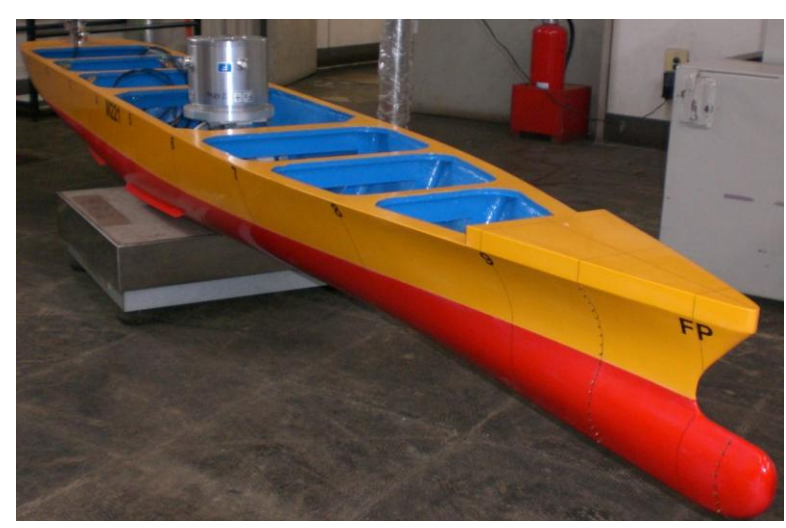

図 1 供試模型船

\section{2. 拘束模型試験}

拘束模型試験は、主に舵角試験を北海道大学の曳 航水槽、また CMT は JMU 運動性能水槽にて実施し た。流体力は図 2 に示すように、原点を船体中央に 固定した座標系に従って計測した。検力計は一点ゲ ージ方式とし、船体中央に取り付けた。なお、一点 ゲージ方式の場合、特に $N$ モーメントが大きく、ゲ ージ歪みも大きくなるため、事前に分力検定を行い、 解析の段階で分力補正を行った。模型船はヒーブ、 ピッチを自由とした。

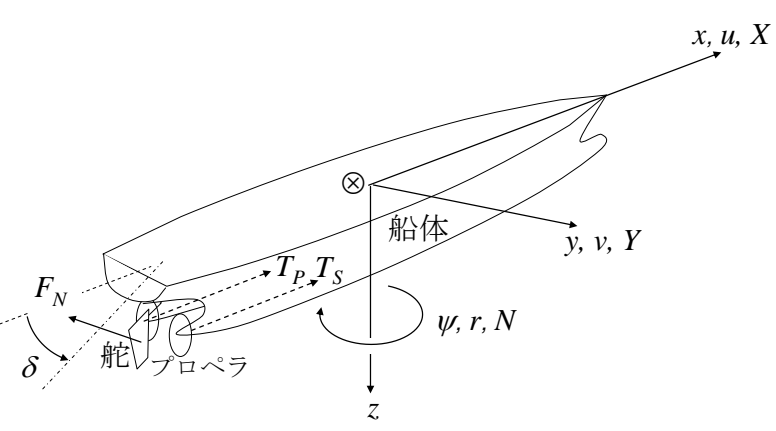

図 22 軸 1 舵の操縦流体力の座標系

舵直圧力は操舵機の舵軸に取り付けた検力計で 計測した。プロペラ推力の計測には 2 台の自航動力 計を使用し、左右のプロペラを同一回転数に設定し た。船速は $1.0 \mathrm{~m} / \mathrm{s}(\mathrm{Fn}=0.209)$ で一定とし、プロペラ 回転数を変えることによって荷重度を変更して実験 を行った。流体力は次式のように無次元化した。た だし、 $L=L_{p p} 、 d=d_{m}$ (平均喫水)、 $\rho$ は水の密度、 $U$ は 船速、 $n$ はプロペラ回転数を表す。

$$
\begin{aligned}
& X^{\prime}=X /\left(\frac{\rho}{2} L d U^{2}\right) \\
& Y^{\prime}=Y /\left(\frac{\rho}{2} L d U^{2}\right) \\
& N^{\prime}=N /\left(\frac{\rho}{2} L^{2} d U^{2}\right) \\
& F_{N}^{\prime}=F_{N} /\left(\frac{\rho}{2} L d U^{2}\right) \\
& K_{T(S)}=T_{S} /\left(\rho D_{P}{ }^{4} n^{2}\right) \\
& K_{T(P)}=T_{P} /\left(\rho D_{P}{ }^{4} n^{2}\right)
\end{aligned}
$$

\section{3. 舵・プロペラの干渉係数}

\section{1 解析方法}

2 軸船において、左右のプロペラ推力 $T_{S}$ (右舷) と $T_{P}$ (左舷)については、直進航走中は基本的に同じで あるが、操舵あるいは旋回・斜航すると、プロペラ の流入速度が左右で異なる結果、左右の推力に差が 生じる。軸間距離が長い場合、これが船に回頭モー メントを与えることになる。しかし、多くの場合、 軸間距離はプロペラ直径のオーダーなので、ここで は左右の推力差を無視して以下の取扱を行う。

(1) 左右のプロペラ推力を合わせて 1 軸のプロ ペラ推力とする。

（2）プロペラ直径を $(\sqrt{2})$ 倍とし、プロペラ回転 数を $(1 / \sqrt{2})$ 倍として解析を行う。 


$$
\left.\begin{array}{l}
n^{*}=n / \sqrt{2} \\
D_{P}^{*}=\sqrt{2} D_{P}
\end{array}\right\}
$$

このような 1 軸相当回転数 $n{ }^{*}$ とプロペラ直径 $D_{P}^{*}$ を用いて解析すると、プロペラの前進定数 $J$ はもと の 2 軸の状態と変わらない他、2 軸合わせたプロペ ラ推力係数も次式で表現できる。

$$
\begin{aligned}
T & =T_{S}+T_{P} \\
& =\rho\left(K_{T(S)}+K_{T(P)}\right) D_{P}{ }^{4} n^{2} \\
& =\rho\left(\frac{K_{T(S)}+K_{T(P)}}{2}\right)\left(\sqrt{2} D_{P}\right)^{4}\left(\frac{1}{\sqrt{2}} n\right)^{2} \\
& =\rho \widetilde{K}_{T} D_{P}^{* 4} n^{* 2}
\end{aligned}
$$

ただし、 $\widetilde{K}_{T}$ は左右のプロペラ推力係数の平均值と なる。

推力減少係数(1- $t)$ は単純に左右のプロペラ推力の 合計から求めることができる。すなおち、

$$
(1-t) T=(1-t)\left(T_{S}+T_{P}\right)=-X_{0}
$$

プロペラの有効伴流係数(1-w)は計測した左右の プロペラ推力から個別に求めたが、直進中は左右で 大きな違いはなく、後述する舵力に及ぼすプロペラ 後流の解析では左右の平均值を用いて解析した。

また、プロペラ有効伴流の運動に対する変化は複 雑であり、これをプロペラ軸間距離や運動の関数と して表すことも可能であるが、この変化は船尾形状 やプロペラ回転方向にも依存し、必ずしも明確でな い。また、特定のプロペラ荷重度における運動変化

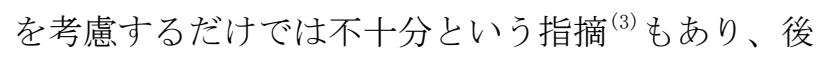
述する操縦運動シミュレーションでは(1-w)を一定 值として取り扱った。

一方、 MMG モデルによる 1 軸 1 舵の舵有効流速 のモデルは次式で表される(3)。ただし、 $\varepsilon$ は $u_{R O} / u_{P}$ $\left(=\left(1-w_{R}\right) /(1-w)\right)$ であり、プロペラの有効伴流係数に対 する舵位置の有効伴流係数の大きさとなっている。 また、 速率を表す。

$$
\begin{aligned}
u_{R}^{\prime} & =\varepsilon(1-w) \\
& \times \sqrt{\eta\left\{1+\kappa\left(\sqrt{1+8 K_{T} /\left(\pi J^{2}\right)}-1\right)\right\}^{2}+(1-\eta)}
\end{aligned}
$$

舵直圧力一致法によって、上記の舵有効流速を解 析するに際しても、（5）式中の $K_{T 、} J 、(1-w)$ の特 性は前述の 1 軸として解析した結果を使用する。た
だし、 $\eta$ はもとのプロペラ直径から求めており、表 1 の要目に掲げた值を使用する。

また、船体の整流係数、および船体と舵との干渉 係数については、MMG モデルではそれぞれ次式で 表される ${ }^{(3)}$ が、2 軸 1 舵船も舵は 1 つであることか ら、1 軸 1 舵船と同じ解析方法が適用できる。

$$
\left.\begin{array}{l}
\beta_{R}=\gamma_{R}\left(\beta-r^{\prime} l_{R}^{\prime}\right) \\
X_{R}^{\prime}=-\left(1-t_{R}\right) F_{N}^{\prime} \sin \delta \\
Y_{R}^{\prime}=-\left(1+a_{H}\right) F_{N}^{\prime} \cos \delta \\
N_{R}^{\prime}=-\left(x_{R}+a_{H} x_{H}\right) F_{N}^{\prime} \cos \delta
\end{array}\right\}
$$

\section{2 解析結果}

2 軸 1 舵の供試模型船の干渉係数を表 2 の左側に 示す。同表の右側には ITTC ベンチマークデータの 供試船となっている 1 軸 1 舵 KCS コンテナ船の各種 の干渉係数 ${ }^{(6)}$ を参考までに比較する。

表 2 干渉係数の比較

\begin{tabular}{|c|c|c|}
\hline \hline & $\begin{array}{c}2 \text { 軸 } 1 \text { 舵 } \\
\text { フェリー }\end{array}$ & $\begin{array}{c}1 \text { 軸 1 舵 } \\
\text { KCS コンテナ船 }\end{array}$ \\
\hline $1-t$ & 0.797 & 0.811 \\
\hline $1-w$ & 0.856 & 0.664 \\
\hline $1-t_{R}$ & 0.853 & 0.558 \\
\hline$a_{H}$ & 0.402 & 0.232 \\
\hline$x_{H}^{\prime}$ & -0.646 & -0.712 \\
\hline$\gamma_{R}$ & 0.393 & 0.412 \\
\hline$\varepsilon$ & 0.737 & 0.906 \\
\hline$\kappa$ & 0.168 & 0.707 \\
\hline$k_{x}$ & 0.124 & 0.641 \\
\hline
\end{tabular}

表 2 より、2 軸 1 舵では $(1-w)$ が大きく、 $\varepsilon$ と $\kappa$ が 通常の 1 軸 1 舵と比べて小さくなっているのが特徵 的である。本供試模型船は両軸をシャフトブラケッ トで支持されているため、プロペラ有効伴流が小さ く、(1-w)が大きくなっている。

また、 $\varepsilon$ は 2 軸 1 舵船では舵位置の伴流がプロペ ラ位置よりも大きくなって $\left(1-w_{R}\right)$ が小さくなるため、 この值が小さい。 左右のプロペラ噴流が舵に当たりにくくなることか ら、この值が低下すると考えられる。

この点について、本論の冒頭にも紹介したように、 湯室 $^{(2)}$ は 2 軸のプロペラ軸間距離 $\left(2 y_{P}\right)$ を種々に変え、 これらのプロペラ後流中の舵角試験を詳細に行って いる。ただし、船体は無い。文献 (2)に掲載されたプ ロペラ推力と舵直圧力の計測結果の図を読み取り、 


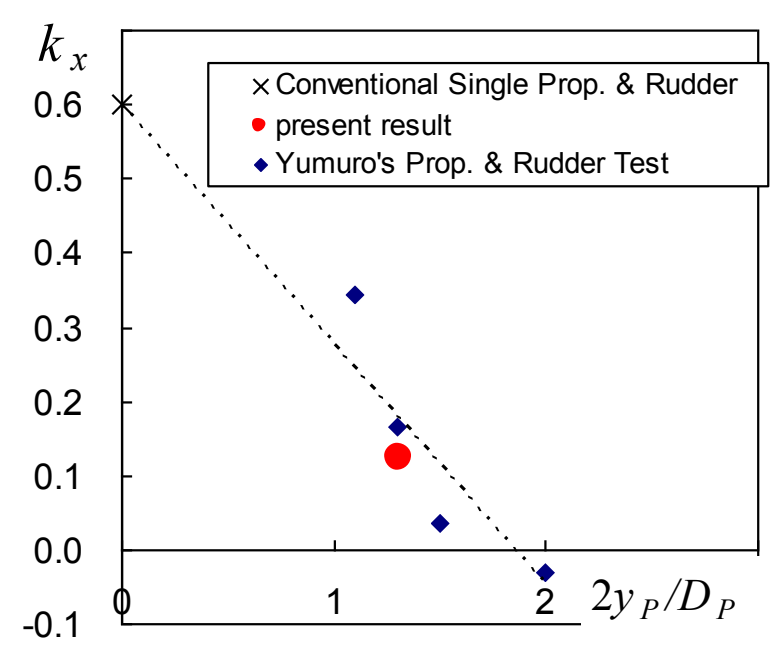

図 32 軸 1 舵のプロペラ後舵角試験結果の再解析 （文献 (2)に掲載された図表からの再解析結果）

これを(3) 式、（5) 式で再解析し、2 軸 1 舵状態のプ ロペラ増速率 $k_{x}$ (この実験では 果を図 3 に示す。横軸がプロペラ直径で無次元化し たプロペラ軸間距離で、プロペラの増速率 $k_{x}$ を縦軸 で表している。また、同図には 1 軸 1 舵船の平均的 なプロペラ増速率 $\left(k_{x}=0.6\right)$ を軸間距離 $=0$ の位置に $\times$ 印で示す。この結果から、軸間距離がプロペラ直径 程度では、 1 軸 1 舵船の約 $1 / 2$ 程度に低下し、本供 試船のように軸間距離がプロペラ直径の 1.3 倍では $1 / 3$ 程度、更に軸間距離が長くなってプロペラ直径 の 2 倍以上になると、2 軸プロペラの後流影響がほ とんど無くなることを示している。

同図には表 2 に示した本供試模型船のプロペラ増 速率を○印で表すが、湯室の実験結果よりやや小さ いものの、これに近い結果が得られており、湯室の 実験結果と整合性がある。

\section{4. 操縦運動シミュレーション}

前述の干渉係数の取り扱いに従つて、2 軸 1 舵の 本供試模型船の操縦運動シミュレーションを行い、 これらを自由航走模型試験結果と比較する。

\section{1 シミュレーションの数学モデル}

シミュレーションを行う数学モデルは、1 軸 1 舵 船の標準的な $\mathrm{MMG}$ 型数学モデルを使用し、プロペ ラ直径を 2 軸の $\sqrt{2}$ 倍とし、プロペラ回転数を $1 / \sqrt{2}$ 倍として計算する。プロペラの推力の $K_{T}-J$ 特性は 2 軸船のプロペラと同じである。

運動方程式は (8) 式に示すとおりで、式中の $u_{G}$ 、
$v_{G} 、 r_{G}$ は船体重心における速度成分を、右辺は船体 中央における定常流体力成分を表す。流体力は MMG の考え方に従って、船体、舵、プロペラの各 力の成分に分離する。

$$
\left.\begin{array}{l}
\left(m+m_{x}\right) \dot{u}_{G}-\left(m+m_{y}\right) v_{G} r_{G}=\frac{\rho}{2} L d U^{2}\left(X_{H}^{\prime}+X_{P}^{\prime}+X_{R}^{\prime}\right) \\
\left(m+m_{y}\right) \dot{v}_{G}+\left(m+m_{x}\right) u_{G} r_{G}=\frac{\rho}{2} L d U^{2}\left(Y_{H}^{\prime}+Y_{R}^{\prime}\right) \\
\left(I_{z z}+J_{z z}\right) \dot{r}_{G} \quad=\frac{\rho}{2} L^{2} d U^{2}\left\{N_{H}^{\prime}+N_{R}^{\prime}-x_{G}^{\prime}\left(Y_{H}^{\prime}+Y_{R}^{\prime}\right)\right\}
\end{array}\right\}
$$

主船体流体力 $X_{H} 、 Y_{H} 、 N_{H}$ は (9) 式に示寸船体中央 における $\beta$ と $r^{\prime}$ の多項式で表す。CMT などの拘束模 型試験で計測された本供試模型船の船体流体力微係 数を表 3 に掲げる。

$$
\left.\begin{array}{rl}
X_{H}^{\prime} & =X_{0}^{\prime}+X_{\beta \beta}^{\prime} \beta^{2}+\left(X_{\beta r}^{\prime}-m_{y}^{\prime}\right) \beta r^{\prime}+X_{r r}^{\prime} r^{\prime 2}+X_{\beta \beta \beta \beta}^{\prime} \beta^{4} \\
Y_{H}^{\prime}= & Y_{\beta}^{\prime} \beta+\left(Y_{r}^{\prime}-m_{x}^{\prime}\right) r^{\prime}+Y_{\beta \beta \beta}^{\prime} \beta^{3} \\
& +Y_{\beta \beta r}^{\prime} \beta^{2} r^{\prime}+Y_{\beta r r}^{\prime} \beta r^{\prime 2}+Y_{r r r}^{\prime} r^{\prime 3} \\
N_{H}^{\prime} & =N_{\beta}^{\prime} \beta+N_{r}^{\prime} r^{\prime}+N_{\beta \beta \beta}^{\prime} \beta^{3} \\
& +N_{\beta \beta r}^{\prime} \beta^{2} r^{\prime}+N_{\beta r r}^{\prime} \beta r^{\prime 2}+N_{r r r}^{\prime} r^{\prime 3}
\end{array}\right\}
$$

表 3 船体流体力微係数

\begin{tabular}{l|r}
\hline \hline$X_{0}^{\prime}$ & -0.0212 \\
$X_{\beta \beta}^{\prime}$ & -0.0348 \\
$X_{\beta r}^{\prime}-m_{y}^{\prime}$ & -0.0957 \\
$X_{r r}^{\prime}$ & -0.0070 \\
$X_{\beta \beta \beta \beta}^{\prime}$ & -0.0018 \\
\hline$Y_{\beta}^{\prime}$ & 0.2501 \\
$Y_{r}^{\prime}-m_{x}^{\prime}$ & 0.0346 \\
$Y_{\beta \beta \beta}^{\prime}$ & 2.6087 \\
$Y_{\beta \beta r}^{\prime}$ & -1.7091 \\
$Y_{\beta r r}^{\prime}$ & 1.1682 \\
$Y_{r r r}^{\prime}$ & -0.0461 \\
\hline$N_{\beta}^{\prime}$ & 0.0966 \\
$N_{r}^{\prime}$ & -0.0513 \\
$N_{\beta \beta \beta}^{\prime}$ & 0.4218 \\
$N_{\beta \beta r}^{\prime}$ & -0.8629 \\
$N_{\beta r r}^{\prime}$ & 0.1459 \\
$N_{r r r}^{\prime}$ & -0.0439 \\
\hline
\end{tabular}

プロペラの力は (2)式に示した 1 軸相当プロペラ 直径 $D_{P}^{*}$ とプロペラ回転数 $n$ をを用いて次式で表す。

$$
X_{P}^{\prime}=2(1-t) K_{T} D_{p}^{* 4} n^{* 2} /\left(L d U^{2}\right)
$$


ただし、 $K_{T}=a_{0}+a_{1} J+a_{2} J^{2}, \quad J=\frac{(1-w) u}{n^{*} D_{P}^{*}}$

また、船体と舵との干渉は既に示した (6)、（7) 式を 用いる。

\section{2 自由航走模型試験}

本供試模型船の自由航走模型試験を実施し、旋回 航跡やスパイラル特性、 $\mathrm{Z}$ 試験の時系列を求めた。 実験は北海道大学水産学部水泳プールと JMU 運動 性能水槽の双方で実施した。船速は実船の航海速力 $(\mathrm{Fn}=0.268)$ 、および半速程度の $\mathrm{Fn}=0.188$ とし、 $\mathrm{GM}$ は実船で $1.87 \mathrm{~m}$ とした。

実験は無線送信機による手動操船で直進させた 後、定常船速に達した時点で自動操舵に切替えて実 施した。舵角、回転数の他、船体運動の回頭角、回 頭角速度については 1 軸ファイバーオプティックジ ヤイロ (FOG)、横傾斜角などは 6 軸慣性ジャイロに よって計測し、航跡や船速は測量で用いられる自動 追尾トータルステーションを用いて陸上から計測し た。船内データと陸上データの同期は、実験開始時 にトータルステーションの反射プリズムを移動させ、 双方のデータに記録される移動記録から同期をとっ た。なお、左右のプロペラは、両舷軸をギアで分割 して左右同じ回転数にした。

\section{3 シミュレーションと自走模型試験の比較}

舵角右 $35^{\circ}$ 旋回航跡のシミュレーション結果を図 4 の曲線で示す。自由航走模型試験の航跡は図中の

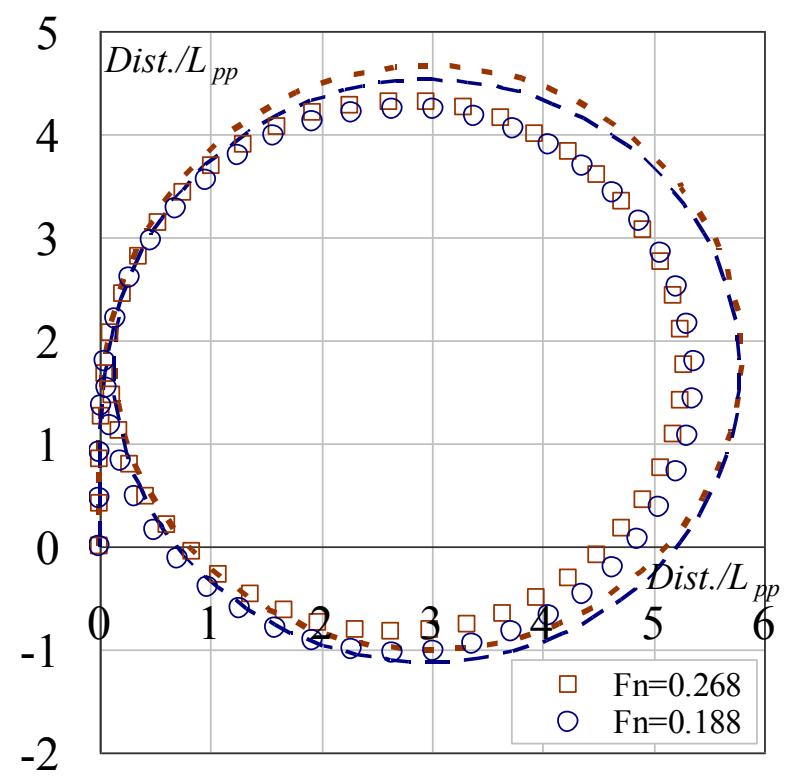

図 4 舵角 $35^{\circ}$ 旋回航跡の比較

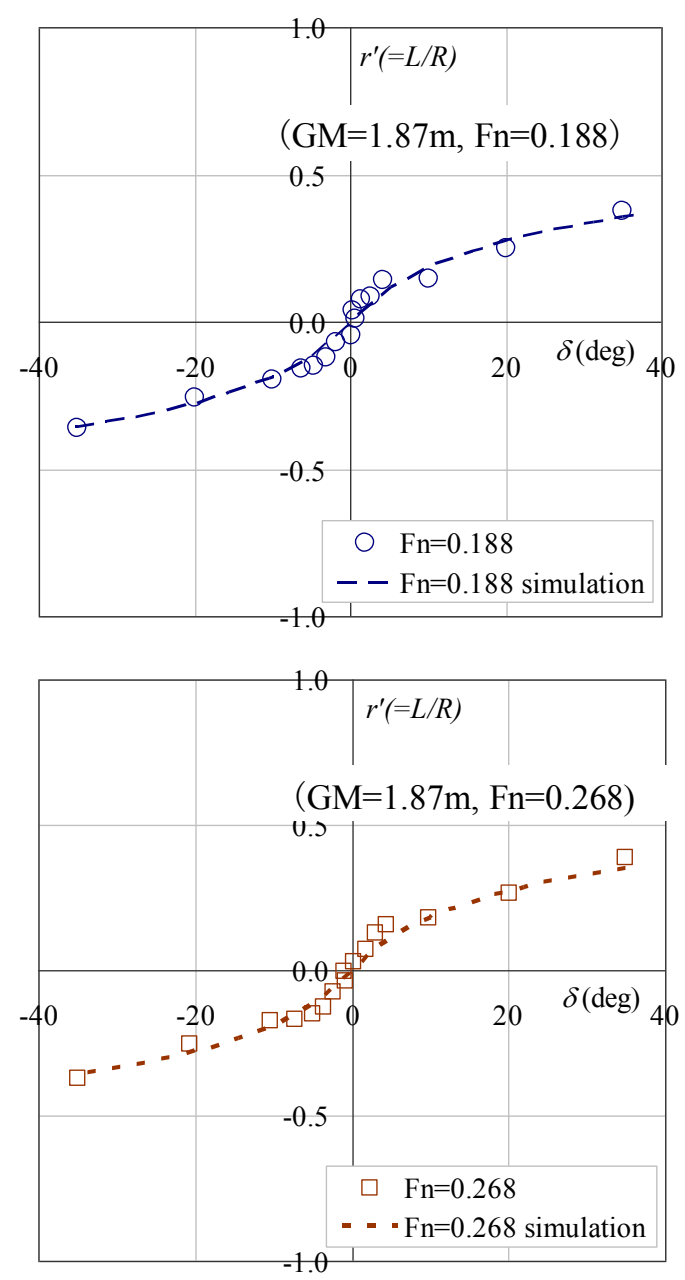

図 5 スパイラル特性の比較

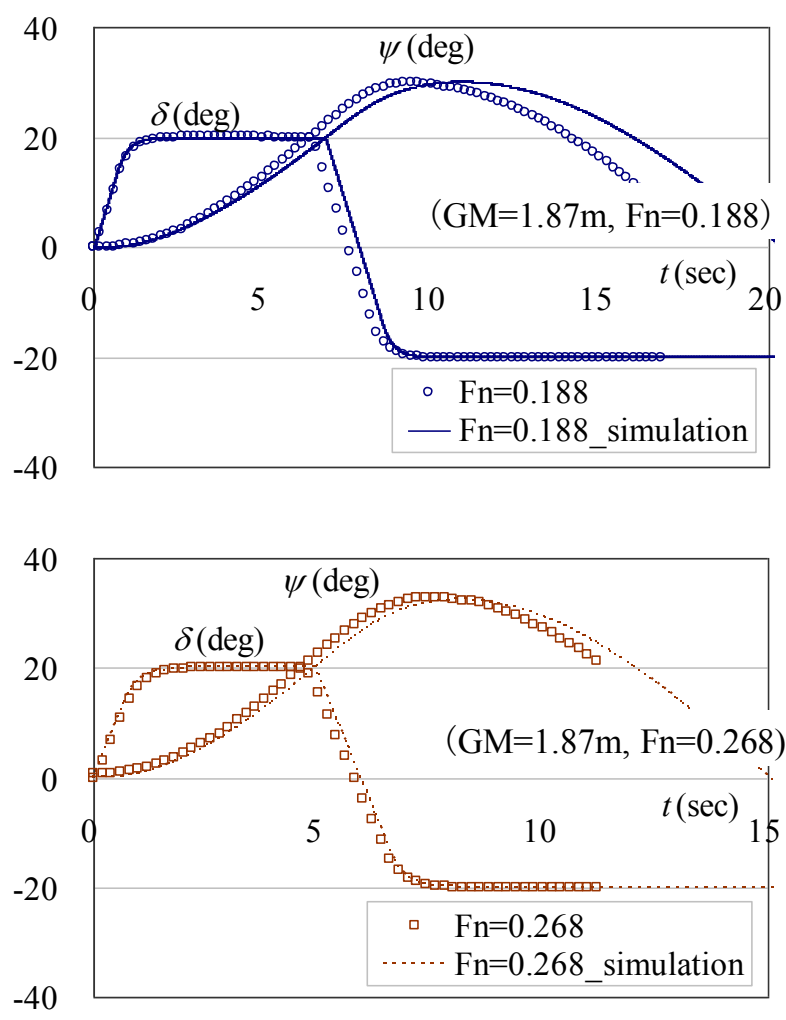

図 $620^{\circ} \mathrm{Z}$ 試験の時系列の比較 
○口印であり、船速が増加するとアドバンスがやや 大きくなっている。シミュレーションの航跡はいず れの船速でも概ね実験結果と一致している。

図 5 には船速毎についてスパイラル特性の比較を 示す。自由航走模型試験結果は上記と同様に○口印 である。これらの比較から、シミュレーション結果 は自由航走模型試験結果と大略一致している。

図6には各船速について $20^{\circ} / 20^{\circ} \mathrm{Z}$ 試験における実 舵角と回頭角の時系列を示す。これらの比較から、

第 1 オーバーシュート角の自由航走模型試験結果と シミュレーション結果がほぼ一致していることがわ かる。

以上の結果より、（2）式に示した 1 軸相当回転数 とプロペラ直径を用いることによって、1 軸 1 舵の 操縦運動数学モデルで 2 軸 1 舵船の操縦運動を推定 できることが確認できた。

\section{5. 結 言}

2 軸 1 舵船の船体・プロペラ・舵の干渉係数につ いて、拘束模型試験結果を解析し、また操縦運動を シミュレーションするに際して、1 軸相当プロペラ 回転数とプロペラ直径を用いることによって、2 軸 1 舵船の操縦運動を容易にシミュレーションできるこ とを示した。

本研究の主な結論を以下に要約する。

1） 2 軸船のプロペラ直径を $(\sqrt{2})$ 倍とし、プロペラ 回転数を $(1 / \sqrt{2})$ 倍として 1 軸 1 舵船と同様な方 法で解析を行い、また操縦シミュレーションに 際しても同じ取扱いをする方法は、2 軸 1 舵船 の簡単で実用的な操縦運動モデルとして大変 有効である。

2）プロペラと舵の干渉係数について、2 軸 1 舵船 では $\varepsilon$ と $k_{x}$ が通常の 1 軸 1 舵と比べて小さくな るのが特徴的である。 $\varepsilon$ はプロペラの有効伴流 係数に対する舵位置の有効伴流係数の大きさ であり、2 軸 1 舵船では舵位置の伴流がプロペ
ラ位置よりも一般に大きいために、この值が小 さくなる。

3）プロペラ増速率 $k_{x}$ の減少は、左右のプロペラ噴 流が舵に当たりにくいことがこの要因である。 この值は、本供試模型船では通常の 1 軸 1 舵船 の $1 / 4$ 程度になったが、湯室の実験結果 ${ }^{(2)}$ を再 解析することによって、この值が妥当である他、 プロペラ軸間距離に大きく依存することが改 めて確認できた。

\section{謝 辞}

本研究の一部はJSPS 科研費 24360353 の助成を受 けたことを付記し関係各位に感謝申し上げます。

\section{参考文献}

（1）玉井浩正・鬼木博文：2 軸高速コンテナ船の操 縦操船試験解析, 関西造船協会誌, 154 号, pp. 41-50, 1974

（2）湯室彰規：2 軸 1 舵船の舵特性に関する実験結 果について，関西造船協会誌，194 号，pp. 53-64， 1984.

（3）小瀬邦治・湯室彰規・芳村康男 : 操縦運動の数 学モデルの具体化, 日本造船学会第 3 回操縦性 シンポジウム, pp. 27-80, 1981.

（4）芳村康男・桜井 仁: 浅水域の操縦運動数学モ デルの検討 (第 3 報) (2 軸 2 舵船の操縦性能につ いて), 関西造船協会誌, 211 号, pp. 115-126, 1987.

（5）李 承建・藤野正隆・深沢塔一：2 軸 2 舵船の 操縦数学モデルについて, 日本造船学会論文集, 163 号，pp. 109-118， 1988.

（6）芳村康男 - 福井 洋 - 横田大武 - 矢野大行 : 横 傾斜を含む 4 自由度操縦運動数学モデルの検討, 日本船舶海洋工学会講演会論文集, 16 号, pp. 17-20, 2013. 